\title{
PENGELOLAAN PEMBELAJARAN BERBASIS WEB PADA MATA PELAJARAN PEMASARAN ONLINE DI SMK NEGERI 1 SRAGEN
}

\author{
Lina Dwi Susanti' ${ }^{1)}$, Budi Murtiyasa' ${ }^{2)}$, dan Sabar Narimo ${ }^{3)}$ \\ ${ }^{1)}$ SMK Negeri 1 Sragen \\ ${ }^{2,3)}$ Magister Administrasi Pendidikan SPs UMS \\ lina_susanti78@yahoo.co.id
}

\begin{abstract}
The objectives of this study were to describe about (1) planning to build a web for online marketing learning in SMK N 1 Sragen; (2) the implementation of the limited test marketing web online learning in SMK N 1 Sragen; (3) evaluation of learning Online Marketing at SMK N 1 Sragen. The method in this study used the research and development (research and Development / $R \& D$ ). Collecting data were through observation, interviews, questionnaires (questionnaire) and documentation. To test the validity of the data used a credibility test (internal validity) and Test transferability (external validity). The conclusion of this study is a web-based learning media on the subjects of online marketing in SMK N 1 Sragen was developed through five stages, namely: (1) preliminary stage (2) the design phase of the product, this stage is the design and preparation of instructional media online marketing, (3) the stage of production, (4) validation phase includes the stage of expert assessment of the product of learning media and (5) the pilot phase of the learners feasible to use for learning marketing online at SMK N 1 Sragen.
\end{abstract}

Keywords: management, learning, online marketing

Abstrak: Penelitian ini bertujuan untuk mendiskripsikan tentang (1) perencanaan dalam membangun web untuk pembelajaran pemasaran online di SMK N 1 Sragen; (2) pelaksanaan ujicoba terbatas web pembelajaran Pemasaran online di SMK N 1 Sragen; (3) evaluasi pembelajaran Pemasaran Online di SMK N 1 Sragen. Metode dalam penelitian ini menggunakan metode penelitian dan pengembangan ( research and Development/ R \& D). Pengumpulan data dengan observasi, wawancara, angket (kuesiomer) dan dokumentasi. Untuk menguji keabsahan data menggunakan Uji credibility (validitas internal) dan Uji transferability (validitas eksternal). Kesimpulan dalam penelitian ini adalah media pembelajaran berbasis web pada mata pelajaran pemasaran online di SMK N 1 Sragen dikembangkan melalui 5 tahap, yaitu : (1) Tahap pendahuluan, (2) Tahap desain produk. Tahap ini merupakan perancangan dan penyusunan media pembelajaran pemasaran online, (3) Tahap Produksi, (4) Validasi tahap validasi ini meliputi tahap penilaian ahli terhadap produk media pembelajaran dan (5) tahap ujicoba terhadap peserta didik layak digunakan untuk pembelajaran pemasran online di SMK N 1 Sragen.

Kata Kunci: pengelolaan, pembelajaran, pemasaran online

\section{Pendahuluan}

Pembelajaran Pemasaran online adalah suatu rangkaian kegiatan belajar mengajar dengan segala hal isinya. Obyek pembelajaran pemasaran online yang berhubungan dengan transaksi jual beli dengan berbantuan internet. 
Dalam hal ini tetap melibatkan dua subjek yaitu pendidik dan peserta didik. Tugas dan tanggung jawab utama seorang pendidik adalah pendidik harus mampu mengelola pembelajaran agar lebih efektif, dinamis dan efisien. Pembelajaran juga diharapkan kearah positif yang ditandai dengan adanya suatu kesadaran dan peranan aktif diantara dua kedua belah pihak baik pendidik maupun peserta didik. Dimana pendidik berperan sebagai organisator, fasilitator dan evaluator sedangkan peserta didik dalam pembelajaran mempunyai peran aktif yang merupakan inti proses pembelajaran yang dilaksanakan.

Pembelajaran itu sendiri merupakan suatu proses kegiatan yang bertujuan untuk menghantarkan peserta didik untuk mencapai tujuan yang menekankan pada hasil belajar yang bermakna. aktivitas yang dilakukan sistematis dan sistemik yang terdiri atas banyak unsur atau komponen. Dalam pengajaran masing masing komponen tidak bisa dipisahkan atau berdiri sendiri sendiri, tetapi harus kesinambungan dan berjalan teratur, komplementer serta saling tergantungan. Untuk semua itu diperlukan suatu pengelolaan pembelajaran. Pengelolaan pembelajaran yang baik harus dikembangkan berdasarkan pada prinsip-prinsip pengajaran yang tepat. serta harus ada perencanaan secara sistematis, bersifat konseptual tetapi praktis realistik dan fleksibel, baik yang menyangkut masalah interaksi pengelolaan kelas, pengajaran, maupun penilaian dalam pengajaran.

Perkembangan ilmu pengetahuan dan teknologi dewasa ini semakin mendorong adanya pembaharuan pemanfaatan teknologi dalam proses pembelajaran sebagai salah satu untuk meningkatkan kualitas pendidikan Peran pendidik tidak hanya sebagai penstranfer ilmu atau informasi tetapi lebih pada bagaimana peserta didik bisa belajar sebaik-baiknya dalam menggunakan media yang menarik termasuk menyediakan berbagai sumber belajar yang bias dipelajari peserta didik. Pembelajaran berbasis web, merupakan salah satu pemanfaatan teknologi dimana situs jenis web biasannya digunakan untuk memposting artikel atau buku harian online. Banyak orang yang membuat web pribadi dan menuliskan tentang pengalaman serta ide ide yang mereka miliki, mereka mendapatkan uang dari kegiatan mereka menulis dan memposting artikel di web. Berbicara tentang web, web merupakan situs jenis web biasannya digunakan untuk memposting artikel atau buku harian online. Banyak orang yang membuat web pribadi dan menuliskan tentang pengalaman serta ide ide yang mereka miliki. Pemilik web disebut dengan weber, saat ini ada juga sebutan profesional weber mereka mendapatkan uang dari kegiatan mereka menulis dan memposting artikel di web.

Jurusan Pemasaran merupakan salah satu kompetensi keahlian yang oleh SMK Negeri 1 Sragen yang saat ini mempunyai lima rombongan belajar untuk masing-masing tingkat. Sesuai dengan visi SMK Negeri 1 Sragen yaitu " mewujudkan SMK Negeri 1 Sragen sebagai penghasil sumber daya manusia yang profesional, berbudi luhur, berwawasan teknologi, dan mandiri dalam bidang Bisnis Manajemen dan Teknologi Informasi dan Komunikasi yang mampu menjawab tantangan zaman". Untuk itu salah satu tujuan kompetensi keahlian Pemasaran di SMK Negeri Sragen adalah menjadi tenaga kerja tingkat menengah untuk mengisi kebutuhan dunia usaha dan industri pada saat ini maupun masa yang akan datang dalam lingkup keahlian bisnis dan manajemen, khususnya bidang pemasaran.

Kompetensi Pemasaran Online membahas semua materi yang terkait dengan membuka peluang para pelaku usaha untuk mengembangkan kegiatan bisnis melalui media elektronik. Sebagian besar pelajaran pemasaran online merupakan kegiatan bisnis yang dilakukan dalam jaringan internet yang merupakan bagian dari e-busines. Pada bagian materi tentang pemasaran online diperlukan media pembelajaran berbasis web berupa latihan atau praktik. Tetapi untuk materi tersebut diperlukan metode dan media 
yang berbeda untuk memberikan variasi dan kemudahan dalam memahami materi tersebut (Kurniasih dan Setiawan, 2013:22).

Agar keberhasilan tujuan pembelajaran Pemasaran online dapat tercapai dengan baik maka diperlukan pengelolaan pembelajaran. Pengelolaan diartikan sebagai suatu metode/ teknik atau suatu proses untuk mencapai suatu tujuan tertentu secara sistematik dan efektif, melalui tindakan-tindakan perencanaan (planning), pengorganisasian (organizing), pelaksanaan (actuating) dan pengawasan (controlling) dengan menggunakan sumber daya yang ada secara efisien (Kodoatie dan Sjarief, 2010: 348).

Tidak dapat dipungkiri dalam pembelajaran pendidik akan menghadapi berbagai keragaman, keragaman itu meliputi keragaman latar belakang budaya, ras, suku, etnik, dan jenis kelamin serta tingkat ekonomi dan banyak lagi untuk itulah diperlukan suatu pengelolaan pembelajaran yang baik. Dimana pengelolaan pembelajaran harus dikembangkan berdasarkan pada prinsipprinsip pengajaran. Pengelolaan pembelajaran harus mempertimbangkan segi dan strategi pengajaran, dirancang secara sistematis, bersifat konseptual tetapi praktis, relistik dan fleksibel, baik yang menyangkut masalah interaksi pengajaran, pengelolaan kelas, pengajaran, maupun penilaian pengajaran. Pada dasarnya tujuan dari pengelolaan pembelajaran adalah tercapainya keserasian antara perencanaan yang telah dibuat dengan kenyataan yang ada di lapangan serta membantu siswa untuk belajar efektif sehingga siswa dapat memperoleh hasil yang diharapkan (Abu,2014:706). Dalam proses pengelolaan pembelajaran Pemasaran online, guru pemasaran yang berperan langsung dalam proses pembelajaran terlibat fungsifungsi pokok yang ditampilkan oleh seorang manajer, yaitu perencanaan (planning), pengorganisasian (organizing), pelaksanaan (actuating), dan evaluasi (controling) dalam pembelajaran.

Mata pelajaran Pemasaran Online sebagai mata pelajaran produktif yang diajarkan kepada siswa jurusan Pemasaran menjadi mata pelajaran yang wajib dikuasai siswa jurusan tersebut. Pada saat ini pembelajaran pemasaran online masih menggunakan media sosial seperti facebook, $B B M$, Whatsapp sehingga belum bisa optimal dalam pengelolaan pembelajaran pemasaran onlinenya. Diharapkan dengan pengelolaan Pembelajaran berbasis web dapat meningkatkan kompetensi siswa jurusan pemasaran kususnya dalam bidang pemasaran online. Pengelolaan pembelajaran Pemasaran di SMK Negeri 1 Sragen yang dilaksanakan agar mempengaruhi kepribadian, perilaku, pengetahuan dan keterampilan siswa setelah mengikuti proses pembelajaran. Artinya, berhasil tidaknya proses pembelajaran akan sangat ditentukan oleh pengelolaan pembelajaran Pemasaran online di SMK Negeri 1 Sragen.

Berangkat dari uraian di atas, peneliti tertarik untuk meneliti tentang pengelolaan pembelajaran Pemasaran Online Adapun judul dalam penelitian ini adalah "Pengelolaan Pembelajaran Berbasis web pada mata pelajaran Pemasaran Online di SMK Negeri 1 Sragen".

Berdasarkan uraian diatas penelitian ini bertujuan untuk : (1) Membuat sebuah media berbasis web untuk mempermudah pengelolaan pembelajaran pemasaran online di SMK negeri 1 Sragen. (2) Mendiskripsikan evaluasi media pembelajaran pemasaran online di SMK Negeri 1 Sragen. (3) Mengetahui hasil ujicoba web dalam pelaksanaan pembelajaran pemasaran online di SMK Negeri 1 Sragen .

\section{Metode}

Metode penelitian yang digunakan adalah metode penelitian dan pengembangan ( research and Development/ $R \& D$ ). Penelitian ini bertujuan untuk membuat media pemebelajaran berbasis web untuk mata pelajaran pemasaran online di SMK N 1 sragen. Wujud data dalam penelitian Research abd Dvelopment diawali dengan tahap pendahuluan dilakukan dengan menerapkan 
pendekatan diskriptif kualitatif dianjutkan dengan tahap pengembangandesain model dilanjutkan penerapan ujicoba terbatas setelah itu diadakan perbaikan dari ujicoba terbatas dan dilanjutkan uji coba yang luas. Kemudian dilakukan tahap validasi model. Nara sumber dapat dimintai keterangan mengenai pengelolaan pembelajaran berbasis web yang terdiri ahli Media yaitu Bapak Pitoyo Meiono, S.T, ahli materi yaitu ibu Murni Wijiastuti, S.Pd, dan Peserta didik kelas X Pemasaran 1 SMK N 1 Sragen. Teknik pengumpulan data dalam penelitian ini menggunakan teknik observasi, wawancara, angket dan dokumentasi. Analisis data dilakukan dengan tahapan Miles dan Huberman (2004:16) yang meliputi : reduksi data ( data reduction), penyajian data ( Data Display), dan kesimpulan dan verifikasi ( Conclusion Drawing/Verification).

Pengecekan keabsahan data dalam penelitian ini menggunakan : (1) Uji credibility (validitas internal), Peneliti menggunakan metode peningkatan ketekunan sebagai alternatif. Meningkatkan ketekunan berarti melakukan pengamatan secara lebih cermat dan berkesinambungan. Upaya peningkatan ketekunan yang dilakukan peneliti diantaranya, membaca berbagai literatur yang berkaitan dengan penelitian dan pengembangan ( Research and Development). Peneliti pun berdiskusi dengan pembimbing mengenai instrumeninstrumen sebelum diujicobakan kepada siswa. (2) Uji transferability (validitas eksternal), Agar laporan penelitian sistematis, rinci dan dapat dipercaya oleh para pembaca, maka peneliti pun melakukan validitas ahli dengan pembimbing agar laporan penelitian tersebut memenuhi standar transferability.

\section{Hasil dan Pembahasan}

Keterlaksanaan pengelolaan pembelajaran berbasis web pada mata pelajaran pemasaran online di SMK N 1 Sragen. Harus memperhatikan beberapa hal antara lain

\section{Proses membuat media pembelajaran} berbasis web untuk mempermudah pengelaan pembelajaran pemasaran online di SMK Negeri 1 Sragen.

Kajian Pustaka merupakan salah satu tahapan pra penelitian dalam jenis penelitian manapun termasuk R\&D. Dalam pengertiannya literature review is a written summary of journal acticles, books and other documents that describes the past and current state of informational; organize literature into topics; and documents a need for a proposed study (creswell, 2008). Dari pengertian tersebut sangat jelas bahwa kegiatan tinjauan pustaka adalah aktivitas menulis kesimpulan yang tertuang dalam jurnal, buku ataupun dokumen lain. Tentunya dokumen yang dirangkum merupakan dokumen yang relevan dengan kegiatan studi yang akan dilakukan.

Diperlukan kecakapan tersendiri bagi seorang peneliti dalam melakukan proses pembuatan media pembelajaran berbasis web. Peneliti harus melakukan aktivitas membaca sebanyak-banyaknya, memilah bahan bacaan yang relevan dan tidak relevan dengan studi yang dilakukan, sehingga ringkasan literatur yang dihasilkan tidak sekedar kumpulan bahan bacaan yang tidak fokus, dimana dengan adanya media pembelajaran dapat meningkatkan kepuasan peserta didik dalam mengikuti pembelajaran pemasaran online. Selain itu peneliti harus terampil dan teliti dalam membuat pengembangan media pembelajaran berbasis web dan semua prosedur harus dijalankan dengan seksama agar tidak terjadi kesalahan dalam pembuatan media. Pada pengembangan media pembelajaran berbasis web terpusat pada bagaimana kesiapan media yang digunakan dalam mempermudah pengelolaan pembelajaran, sehingga komponen kegiatan belajar dan proses pelaksanaan program pembelajaran berbasis web berjalan dengan baik. Dengan demikian media pembelajaran berbasis web dapat digunakan untuk kegiatan belajar mengajar pada mata pelajaran Pemasaran online di SMK Negeri 1 Sragen. Hal ini dapat dilihat pada alamat pmonline. bcsmkn1srg.net dimana alamat tersebut mencakup pembahasan materi pemasaran 
online serta evaluasi yang dilakukan guru untuk mengetahui sejauh mana daya serap atau uji kompetensi siswa terhadap sub materi pembelajaran konsep pemasaran online. Sedangkan bcsmkn1srg.net merupakan alamat untuk praktek nyata siswa dalam melakukan pemasaran online. Hasil penelitian terdahulu yang dilakukan oleh Mei Ying \& Li Hsia Tseng (2014), hasil penelitian menunjukkan bahwa persepsi pemasaran memiliki pengalaman yang berbeda secara signifikan pada beberapa variabel demografis, dimana pemasaran mempunyai hubungan positif dengan kepuasan pelanggan dan loyalitas pelanggan, kepuasan pelanggan dan loyalitas pelanggan secara positif terkait dengan pemasaran. Hal ini menunjukkan persepsi pemasaran mempunyai hubungan positif dengan kepuasan pelanggan dan loyalitas pelanggan. Untuk menguji faktor - faktor yang mempengaruhi kepuasan pelanggan banyak dilakukan dipasar konsumen melalui marketing online hal ini dikarenakan menggunakan fasilitas internet dapat menunjukan hubungan yang signifikan terhadap nilai produk, kualitas E-layanan, biaya yang lebih efektif dibandingkan dengan pemasaran yang dilakukan secara ofline.

\section{Evaluasi Aspek Media pembelajaran berbasis web pada mata pelajaran pemasran online di emasran online di SMK Negeri 1 Sragen.}

Penilaian aspek media dilakukan oleh ahli media dan guru. Bapak Pitoyo meiono, S.T sebagai ahli media dan Ibu Murni Wijiastutik, S.Pd sebagai guru SMK N 1 Sragen. Penilaian aspek media dan aspek materi menggunakan angkert dengan skala Likert. Ahli media memberikan penilaian dengan empat kategori yaitu sangat baik, baik, kurang dan sangat kurang. Ada empat komponen yang dinilai dalam aspek media yaitu kualitas isi, tampilan, interaksi, dan rekayasa perangkat lunak.

a. Penilaian aspek media

Tabel 11

Data penilaian Kualitas isi

\begin{tabular}{|c|c|c|c|}
\hline \multirow{2}{*}{ No. } & \multirow{2}{*}{ Aspek Penilaian } & \multicolumn{2}{|c|}{ Penilaian } \\
\hline & & Ahli Media & Ahli Materi \\
\hline 1 & $\begin{array}{l}\text { Relevansi indikator dan tujuan } \\
\text { pembelajaran dengan standar } \\
\text { kompetensi }\end{array}$ & A & A \\
\hline 2 & $\begin{array}{l}\text { Penyajian Materi secara rinci dan } \\
\text { sistematis }\end{array}$ & A & A \\
\hline 3 & $\begin{array}{l}\text { Dukungan link situs pemasaran online } \\
\text { untuk memperluas pemahaman peserta } \\
\text { didik }\end{array}$ & A & A \\
\hline 4 & Kesesuaian evaluasi dengan materi & A & A \\
\hline \multicolumn{4}{|c|}{ Rata-rata penilaian $=100 \%$} \\
\hline
\end{tabular}

Berdasarkan tabel 12 diatas hasil penilaian ahli media dan ahli materi adalah $100 \%$ sehingga hasil media pembelajaran pemasran online dilihat dari kwalitas isi berkategori sangat baik. 
Tabel 12

Hasil kwalitas tampilan

\begin{tabular}{|c|c|c|c|}
\hline \multirow{2}{*}{ No } & \multirow{2}{*}{ Aspek Penilaian } & \multicolumn{2}{|c|}{ Penilaian } \\
\hline & & Ahli Media & Ahli Materi \\
\hline 1 & $\begin{array}{l}\text { Kreativitas dalam ide dan penuangan } \\
\text { gagasan }\end{array}$ & A & A \\
\hline 2 & $\begin{array}{l}\text { Komposisi link pada setiap Web } \\
\text { mudah dipahami }\end{array}$ & A & A \\
\hline 3 & Tampilan menu mudah dipahami & A & A \\
\hline 4 & $\begin{array}{l}\text { Link ke produk produk yang } \\
\text { ditampilkan menarik }\end{array}$ & A & A \\
\hline 5 & $\begin{array}{l}\text { Pilihan jenis dan ukuran font } \\
\text { mempermudah keterbacaan }\end{array}$ & A & A \\
\hline 6 & Penggunaan bahasa komunikatif & A & A \\
\hline & Rata rata nilai $=$ & $0 \%$ & \\
\hline
\end{tabular}

Berdasarkan tabel 13 diatas hasil pembelajaran pemasran online dilihat penilaian ahli media dan ahli materi adalah $100 \%$ sehingga hasil media dari kwalitas tampilan berkategori sangat baik.

Tabel 13

Hasil Penilaian Kualitas Interaksi

\begin{tabular}{|c|c|c|c|}
\hline \multirow{2}{*}{ No } & \multirow{2}{*}{ Aspek Penilaian } & \multicolumn{2}{|c|}{ Penilaian } \\
\hline & & Ahli Media & Ahli Materi \\
\hline 1 & $\begin{array}{l}\text { Kemungkinan peserta didik mudah dalam } \\
\text { belajar mandiri dengan media }\end{array}$ & A & A \\
\hline 2 & $\begin{array}{l}\text { Terjadinya interaksi nyata antara peserta } \\
\text { didik dengan media pembelajaran pemasaran } \\
\text { online }\end{array}$ & A & A \\
\hline \multicolumn{4}{|c|}{ Rata rata nilai $=100 \%$} \\
\hline
\end{tabular}

Berdasarkan tabel 13 diatas hasil penilaian ahli media dan ahli materi adalah $100 \%$ sehingga hasil media pembelajaran pemasaran online dilihat dari kwalitas interaksi berkategori sangat baik.

Tabel 14

Hasil penilaian Kualitas Rekayasa Perangkat Lunak

\begin{tabular}{|c|c|c|c|}
\hline \multirow{2}{*}{ No } & \multirow{2}{*}{ Aspek Penilaian } & \multicolumn{2}{|c|}{ Penilaian } \\
\hline & & Ahli Media & Ahli Materi \\
\hline 1 & $\begin{array}{l}\text { Usabilitas ( mudah digunakan dan sederhana } \\
\text { dalam pengoperasiannya ) }\end{array}$ & A & A \\
\hline 2 & $\begin{array}{l}\text { Kompabilitas ( media pembelajaran dapat } \\
\text { diinstalasikan diberbagai hardware dan } \\
\text { software yang ada) }\end{array}$ & A & A \\
\hline & Rata rata nilai $=100 \%$ & & \\
\hline
\end{tabular}

Berdasarkan tabel 14 diatas hasil penilaian ahli media dan ahli materi adalah $100 \%$ sehingga hasil media pembelajaran pemasaran online dilihat 
dari kwalitas Rekayasa Perangkat Lunak berkategori sangat baik.

Secara umum aspek media dalam perencanaan pembuatan web ini berkategori sangat baik dilihat dari penilaian aspek kualitas isi, tampilan, kualitas interaksi serta kualitas rekayasa perangkat lunak.

b. Analisis Data Hasil Penilaian Aspek

Materi

Penilaian aspek materi yang disajikan dalam pembelajaran pemasaran online yang dilakukan oleh ahli materi dan guru. Ibu Murni Wijiastuti, S.Pd guru Pemasran online SMK N 1 Sragen. Penilaian aspek materi menggunakan angket dengan cek list kebenaran konsep ( benar dan Salah ). Ahli Materi memberi penilaian dengan mencentang kebenaran konsep materi. Penilaian aspek materi meliputi isi dari konsep Pemasaran online.

Tabel 15

Hasil Penilian kebenaran konsep materi

\begin{tabular}{|c|c|c|c|}
\hline \multirow{2}{*}{ No } & \multirow{2}{*}{ Aspek Penilaian } & \multicolumn{2}{|c|}{ Penilaian } \\
\hline & & Ahli Media & Ahli Materi \\
\hline 1 & $\begin{array}{l}\text { Memahami pengertian pemasaran } \\
\text { online }\end{array}$ & A & A \\
\hline 2 & Manfaat Pemasaran online & A & A \\
\hline 3 & $\begin{array}{l}\text { Mengidentifikasi komponen komponen } \\
\text { pemasaran online }\end{array}$ & A & A \\
\hline 4 & Cara kerja pemasaran online. & A & A \\
\hline & Rata - rata penilaian $=$ & $00 \%$ & \\
\hline
\end{tabular}

Berdasarkan tabel 15 diatas hasil penilaian ahli media dan ahli materi adalah $100 \%$ sehingga hasil media pembelajaran pemasaran online dilihat dari kebenaran konsep materi berkategori sangat baik.

Dalam evaluasi Aspek Media pembelajaran berbasis web pada mata pelajaran pemasran online di SMK Negeri 1 Sragen. Penelitian ini juga ada kesamaan dengan penelitian Maktoba Omar ( 2006 ) Penelitian ini bertujuan untuk menguji faktor-faktor yang mempengaruhi kepuasan pelanggan di kalangan pembeli online di Cina. Ini berlaku kategori normatif diidentifikasi dalam literatur dan menguji mereka untuk efek di pasar konsumen Cina secara online muncul.

Kesamaan penelitian ini ditunjukkan dengan adanya kesamaan evaluasi terhadap produk untuk mengetahui tingkat kepuasan para peserta didik terhadap media pembelajaran yang kita buat. Sehingga media pembelajaran dapt digunakan untu mata pelajaran pemasaran online di SMK N 1 Sragen

\section{Hasil Uji Coba media pembelajaran berbasis web pada mata pelajaran pemasaran online di SMK Negeri 1 Sragen}

Ujicoba satu-satu, ujicoba kelompok kecil dan uji coba lapangan dilakukan di SMK N 1 Sragen. Uji Coba Satu satu dilaksanakan pada tanggal 10 Agustus 2015, uji coba kelompok kecil dilaksanakan pada tanggal 24 Agustus 2015, dan ujicoba lapangan dilaksanakan pada tanggal 7 September 2015 dan 14 September 2015. Peserta didik yang digunakan uji coba satu- satu adalah peserta didik kelas X PM 1 berjumlah tiga orang peserta didik, Pemilihan peserta didik berdasarkan tingkat prestasi peserta didik yang terdiri dari satu 
peserta didik dengan prestasi tinggi, satu peserta didik dengan prestasi sedang dan satu peserta didik dengsn prestasi rendah, Ujicoba kelompok kecil menggunakan 6 orang peserta didik kelas X PM 2 yang terdiri dari dua peserta didik berprestasi rendah, dua orang peserta didik berprestasi sedang dan tiga peserta didik berprestasi belajar tinggi. Sedangkan ujicoba lapangan menggunakan peserta didik kelas X PM 1yang terdiri dari 32 peserta didik ( satu kelas ). Tujuan utama dari ujicoba satu-satu dan ujicoba kelompok kecil untuk mengetahui tanggapan peserta didik tentang kwalitas konsep pemasasaran online yang telah disusun. Ujian lapangan bertujuan untuk mengetahui tanggapan peserta diidik tentang kwalitas konsep pemasasaran online yang telah disusun.

Tabel 16

Hasil Tanggapan Peserta Didik terhadap Media Bebasis Web Pemasaran Online

\begin{tabular}{|c|c|c|c|c|}
\hline \multirow[b]{2}{*}{ No } & \multirow[b]{2}{*}{ Pernyataan } & \multicolumn{3}{|c|}{ Tanggapan Peserta didik Uji Coba } \\
\hline & & Satu - satu & $\begin{array}{c}\text { Kelompok } \\
\text { kecil }\end{array}$ & Lapangan \\
\hline 1 & $\begin{array}{l}\text { Bahasa yang digunakan sederhana } \\
\text { dan mudah dipahami }\end{array}$ & A & A & A \\
\hline 2 & $\begin{array}{l}\text { Petunjuk penggunaan mudah } \\
\text { dipahami }\end{array}$ & B & B & A \\
\hline 3 & $\begin{array}{l}\text { Tampilan menu navigasiyang } \\
\text { disajikan mudah dipahami }\end{array}$ & $\mathrm{A}$ & A & A \\
\hline 4 & $\begin{array}{l}\text { Kalimat pada materi tidak } \\
\text { menimbulkan makna ganda }\end{array}$ & A & A & A \\
\hline 5 & $\begin{array}{l}\text { Materi yang disampaikan dengan } \\
\text { sederhana dan mudah dipahami }\end{array}$ & $\mathrm{A}$ & A & A \\
\hline 6 & $\begin{array}{l}\text { Penggunaan bahasa yang } \\
\text { komunitatif sehingga materi mudah } \\
\text { untuk dipahami }\end{array}$ & A & A & A \\
\hline 7 & $\begin{array}{l}\text { Pilihan jenis dan ukuran font sudah } \\
\text { tepat sehingga dapat mempermudah } \\
\text { memahami materi. }\end{array}$ & $\mathrm{A}$ & A & A \\
\hline
\end{tabular}

Berdasarkan tabel 16 diatas hasil tanggapan peserta didik terhadap media berbasis web pemasaran online adalah $100 \%$ sehingga hasil media pembelajaran pemasaran online dilihat dari Data Tanggapan peserta didik berkategori sangat baik.

Dari uraian pembahasan diatas ada beberapa kesamaan penelitian Simona Vinerean, Iuliana Cetina, Luigi Dumitrescu \& Mihai Tichindelean ( 2013 ). penelitian mengenai aktivitas online dari 236 pengguna media sosial, dengan mengidentifikasi berbagai jenis pengguna, segmentasi dari para pengguna dan model linier untuk memeriksa bagaimana prediktor yang berkaitan dengan situs jaringan sosial yang berbeda memiliki positif dampak pada persepsi responden terhadap iklan online.

Kesamaan penelitian ini ditunjukkan dengan adanya kesamaan dalam melakukan uji coba terhadap produk yang dikembangkan untuk memperoleh hasil memuaskan sesuai dengan yang diinginkan.

\section{Simpulan}

Berdasarkan hasil analisis data yang telah dilakukan maka dapat disimpulkan bahwa : Media pembelajaran berbasis web pada mata pelajaran pemasaran online untuk peserta didik SMK N 1 Sragen dikembangkan melalui 5 tahap, yaitu:(1) Tahap pendahuluan, meliputi survei lapangan atau analisis proses 
pembelajaran, analisis peserta didik, dan analisis materi. (2) Tahap desain produk. Tahap ini merupakan perancangan dan penyusunan media pembelajaran pemasaran online, (3) Tahap Produksi dan Validasi tahap validasi ini meliputi tahap penilaian ahli terhadap produk media pembelajaran dan tahap ujicoba. Penilaian media peembelajaran dilakukan oleh reviewer internal yang terdiri dari ahli materi dan ahli media, reviewer ekternal terdiri dari guru pemasaran online, sedangkan tahap uji coba meliputi tahap uji coba perorangan ( satu - satu ) uji coba kelompok kecil dan uji coba lapangan.

Kualitas media pembelajaran berbasis web submateri konsep pemasaran online di tinjau dari aspek media berkategori sangat baik yaitu pada kualitas isi, kualitas tampilan sdan bahasa, kualitas interaksi, dsn kuslitas rekayasa perangkat lunak dan aspek materi sangat baik yaitu kebenaran konsep materi $100 \%$ hal ini menunjukan media pembelajaran berbasis web layak digunakan dalam pembelajaran.

Berdasarkan tanggapan peserta didik terhadap media pembelajaran berbasis web sub materi konsep pemasaran online memiliki kualitas baik sehingga dapat membantu memahami sub materi tersebut.

\section{Daftar Pustaka}

Ahmadi, Iif Khoiru; Amri, Sofan dan Elisah, Tatik. 2011. Strategi Pembelajaran Sekolah Terpadu. Jakarta: PT. Prestasi Pustakaraya.

Arikunto, Suharsimi. 2010. Prosedur Penelitian Suatu Pendekatan Praktik. Edisi Revisi. Jakarta: PT.Rineka Cipta

Aunurrahman. 2009. Belajar dan Pembelajaran. Bandung: Alfabeta.

Borg, W.R \& Gall, M.D. 1983. Eucation research: an introduction.4 ${ }^{\text {th }}$ Edition. New York: Longman Inc

Hamzah B.Uno. 2007 Perencanaan Pembelajaran. Jakarta: PT Bumi Aksara.

Haryanto, Suyono.2014. Belajar dan Pembelajaran. Bandung: PT. Remaja Rosdakarya.

Sanaky, Hujair. 2009. Media Pembelajaran. Yogyakarta: Safiria Insania Press.

Nana Sudjana \& Ahmad Rivai. 2011. Media Pengajaran. Bandung: Sinar Baru Algensindo

Majid Abdul. 2013 . Strategi Pembelajaran. Bandung: Remaja Posdakarya.

Moleong, Lexy J. 2014. Metode penelitian kualitatif. Bandung: PT. Remaja Rosdakarya

Mulyasa.2003 . Manajemen Berbasis Sekolah. Bandung: Remaja Posdakarya.

Rohiat. 2008. Manajemen Sekolah. Teori Dasar dan Praktik Dilengkapi dengan Contoh Rencana Strategis dan Rencana Operasional. Bandung: PT. Refika Aditama.

Riduwan. 2010. Skala Pengukuran Variabel-Variabel Penelitian. Bandung: Alfabeta.

Sagala, Syaiful. 2009. Manajemen Strategik dalam Peningkatan Mutu Pendidikan. Bandung: CV. Alfabeta.

Sanjaya, Wina. 2008. Kurikulum dan Pembelajaran. Jakarta: Kencana

Sugiyono. 2011. Metode Penelitian Pendekatan Kuantitatif, Kualitatif dan R\& D. Bandung: ALFABETA.

Suyono \& Hariyanto. 2011. Metode Belajar Mengajar. Bandung: Remaja Posdakarya. 
Hamza Salim Kharim \& ala 'a atef Al Karableiah 2015 .The Effect of Using Pay Per Click Advertisement on Online Advertisement Effectiveness and Attracting Customers in E-marketing Companies in Jordan

Hamed Armesh Multimedia, 2009. Impact of Online/Internet Marketing on Computer Industry in Malaysia in Enhancing Consumer Experience

Maktoba Omar 2006. Internet marketing and customer satisfaction in emerging markets: the case of Chinese online shoppers

Mei Ying \& Li Hsia Tseng, 2014 .Customer Satistation and loyalty in an online Shop : An experiential Marketing Perspective. 